\title{
Temporal Variation In Fecundity And Spawning In The Eastern Oyster, Crassostrea Virginica, In The Piankatank River, Virginia
}

\author{
Roger L. Mann \\ Virginia Institute of Marine Science \\ Melissa Southworth \\ Virginia Institute of Marine Science \\ Ryan B. Carnegie \\ Virginia Institute of Marine Science \\ Rita K. Crockett \\ Virginia Institute of Marine Science
}

Follow this and additional works at: https://scholarworks.wm.edu/vimsarticles

Part of the Marine Biology Commons

\section{Recommended Citation}

Mann, Roger L.; Southworth, Melissa; Carnegie, Ryan B.; and Crockett, Rita K., Temporal Variation In Fecundity And Spawning In The Eastern Oyster, Crassostrea Virginica, In The Piankatank River, Virginia (2014). Journal Of Shellfish Research, 33(1), 167-176.

10.2983/035.033.0116

This Article is brought to you for free and open access by the Virginia Institute of Marine Science at W\&M ScholarWorks. It has been accepted for inclusion in VIMS Articles by an authorized administrator of W\&M ScholarWorks. For more information, please contact scholarworks@wm.edu. 


\title{
TEMPORAL VARIATION IN FECUNDITY AND SPAWNING IN THE EASTERN OYSTER, CRASSOSTREA VIRGINICA, IN THE PIANKATANK RIVER, VIRGINIA
}

\author{
ROGER MANN,* MELISSA SOUTHWORTH, RYAN B. CARNEGIE AND RITA K. CROCKETT \\ Virginia Institute of Marine Science, College of William and Mary, PO Box 1346, 1375 Greate Road, \\ Gloucester Point, VA 23062
}

\begin{abstract}
Oysters of the genus Crassostrea are considered good examples of an r-selected marine invertebrate with small egg size, high fecundity, and multiple spawning events per year, each characterized by significant individual weight loss. Historical (decadal) data for the Virginia portion of the Chesapeake Bay support these generalities. We present recent (subdecadal) data, collected for natural Crassostrea virginica broodstock of populations in the Piankatank River, Virginia. The relationship is described between oyster size, fecundity, spawning periodicity, and egg viability for natural broodstock. Oysters collected throughout the summers of 2010 through 2012 and induced to spawn by thermal cycling released viable eggs on 7 dates ( $\mathrm{n}=119$ oysters, 35 male, 84 female; shell length (SL) range, $58-113 \mathrm{~mm}$ ). Oysters were opened to examine sex ratio on four additional dates (total $\mathrm{n}=242$ oysters, 82 male, 160 female). Fecundity varied in the range $10^{5}-1.2 \times 10^{8}$ eggs. When all data are considered in unison, no strong relationship with SL is evident; however, when eliminating the artifact of data corresponding to minimal egg release, a much stronger relationship, comparable with that reported in older literature, emerges. Female fraction (Female/(Female + Male)) was consistently more than 1 in oysters larger than $60 \mathrm{~mm}$ in SL (estimated age, $\geq 2 \mathrm{y}$ ), generally in accordance with recently published literature on the species in the mid-Atlantic. The size-versus-fecundity relationship does not appear to be greatly influenced by disease prevalence/ intensity. The temporal sequence of spawning activity was not observed to continue after midsummer and is not commensurate with a cumulative degree-day estimator during the latter half of the well-documented historical spawning season. A size-fecundity estimator for the Piankatank River oysters provides a basis to estimate the disproportionate value of larger/older ( $\geq 3$ y) oysters in the system, and provides additional input to the fine-tuning of a previously developed rotational harvest schedule for the river stock. The possible impact of recent changes in water quality, seasonal occurrence of dinoflagellate blooms, and/or long-term impacts of changing regimes were not examined in detail in this study but are suggested as worthy lines of future investigation.
\end{abstract}

KEY WORDS: eastern oyster, Crassostrea virginica, fecundity, Perkinsus marinus, Haplosporidium nelsoni, recruitment

\section{INTRODUCTION}

The eastern oyster Crassostrea virginica (Gmelin 1791) is described as an r-selected protandric hermaphrodite with a type 3 mortality curve and a life expectancy in excess of $10 \mathrm{y}$ in undisturbed populations (Powell \& Cummins 1985, Thompson et al. 1996). Its complex life history traits include high fecundity, external fertilization through coordinated mass spawning, and a planktotrophic larval form. Fecundity is related positively to body size (Galtsoff (1930), Cox and Mann (1992) as also cited in Choi et al. (1993), Thompson et al. (1996)). Multiple spawnings per year are expected in the southern reaches of the occupied range and are generally predictable using degree-day estimators (Price \& Maurer 1971, Mann et al. 1994). Spawning results in considerable loss in individual weight (Gunter 1942, Engle 1950, Gabbott 1975). Gregarious settlement of juveniles on the growing edges of adults promotes reef accretion and the perpetuation of the species in the geologically ephemeral estuarine environment (Mann et al. 2009a). This life history construct prompts numerous quantitative questions. At what age/size does the male-to-female transition occur? How does variation in the male-to-female transition affect population level fecundity? Are the described life history traits plastic? If so, will this plasticity emerge in populations truncated in age/size by harvests, predation, diseases, and/or environmental stress? Can fecundity and sex ratio estimates be used in conjunction with density and population demographic data to develop spawner-recruit relationships that have proved so valuable in finfish fisheries but are essentially absent as management tools

*Corresponding author. E-mail: rmann@vims.edu DOI: $10.2983 / 035.033 .0116$ in oyster fisheries? Only recently have these basic questions been addressed, with much work still in progress.

All the previously listed questions are pertinent to the management of extant oyster populations in the Chesapeake Bay, where historical harvests and, more recently, disease pressure have had a notorious impact (Andrews \& Wood 1967, Burreson \& Andrews 1988, Newell 1988, Burreson \& Ragone Calvo 1996), reducing both population size and arguably truncating age structure. Harding et al. (2013) described the sex ratio-versus-size relationship in oysters from subestuaries of Chesapeake Bay, revealing remarkable similarity to observations by Powell et al. (2013) for oysters from Delaware Bay, a strong predominance by number of males but by weight of females. Mann et al. (2009b), Southworth et al. (2010), and Harding et al. (2010) provided a comprehensive description of spatial population structure, including size and age demographics and shell budget in the James River, Great Wicomico River, and Piankatank River, respectively-all Virginia subestuaries of the Chesapeake Bay. Harvest in the Piankatank River is limited to a well-regulated seed oyster fishery that has been executed for in excess of $25 \mathrm{y}$, and for which long-term monitoring of both oyster recruitment (reviewed in Southworth and Mann $(2004,2013)$ ) and disease (both Perkinsus marinus and Haplosporidium nelsoni) (e.g., Carnegie \& Burreson 2011) occur. The importance of the shell budget in long-term stability of oyster populations has only recently been adequately appreciated (Powell et al. 2006, Mann \& Powell 2007, Powell \& Klinck 2007). A shell-neutral (no net loss) rotational harvest protocol is outlined in Harding et al. (2010) as a mechanism to sustain the population in the absence of shell planting. Absent from that analysis is a detailed 
examination of the size-versus-age-versus-fecundity relationship of the extant population, and a consideration of the impact of enzootic diseases on that relationship. Fecundity remains a key question, particularly given earlier documented detrimental impacts of parasitism on gamete production. Both P. marinus and H. nelsoni have been documented to reduce oyster fecundity, with impacts increasing as infections intensify (Barber et al. 1988, Ford \& Figueras 1988, Kennedy et al. 1995, Dittman et al. 2001). In recent years, however, evidence suggests that Crassostrea virginica has adapted to intensified disease by developing a level of disease resistance (e.g., Carnegie \& Burreson 2011). In recognition of this changing background, restoration efforts have sought to protect putatively resistant broodstock, but the fecundity of larger/older survivors of annual epizootics has been uncertain. To extend the aforementioned analyses and provide critical perspective on oyster fecundity, the current study seeks to examine the individual size-versus-fecundity relationship and the influence of disease on spawning, and the importance of older year classes in total egg production within the considered population.

\section{MATERIALS AND METHODS}

\section{Field Location}

The Piankatank River is a small estuary (watershed area, $466 \mathrm{~km}^{2}$ (Chen et al. 1977)) located on the western shore of the
Chesapeake Bay in Virginia. Andrews (1979) described it as a trap-type estuary, noted for high and regular recruitment of oysters. It is managed by the Virginia Marine Resources Commission (VMRC) as a source of oyster seed for transplant to other locations in the Virginia portion of the Chesapeake Bay. A recent description of oyster stocks in the river is given by Harding et al. (2010). Figure 1, taken directly from that publication, provides a background to the local distribution of the stock and sampling location for the current study. The study was effected during summer 2010, 2011, and 2012. Temperature and salinity during the period of collection was recorded at 15-min intervals using the YSI 600 Series sonde (Yellow Springs Instruments) maintained at $0.5 \mathrm{~m}$ above the bottom at Palace Bar Reef (location 2 in Fig. 1), as described in Harding et al. (2010). When sonde data were unavailable, data values were taken from weekly field measurements, per Southworth and Mann (2013), with interpolations to provide daily estimates.

\section{Estimation of Oyster Fecundity and Egg Viability}

Oysters were collected by dredging at Ginney Point in the Piankatank River, Virginia (location 1 in Fig. 1, dates in Table 1) and transferred to a local oyster hatchery at Oyster Seed Holdings LLC (OSH), Gwynn's Island, Mathews County, Virginia (Fig. 1, within $10 \mathrm{~km}$ of the collection site). The target

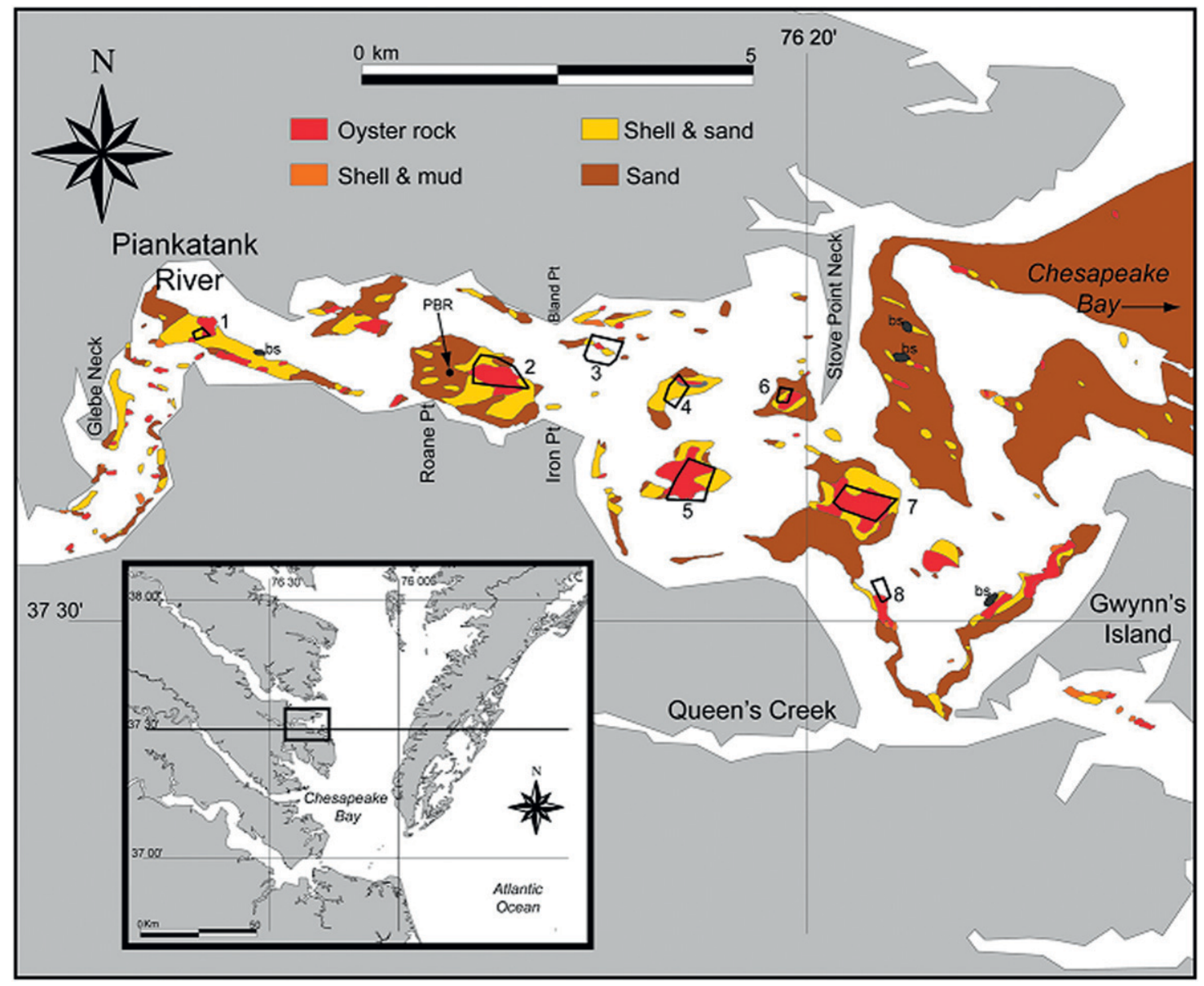

Figure 1. Location of the 8 public reefs in the Piankatank River, Virginia. Reefs are as follows: 1, Ginney Point, collection location for the current study; 2, Palace Bar; 3, Bland Point; 4, Heron Rock; 5, Cape Toon; 6, Stove Point; 7, Burton Point 1; and 8, Burton Point 2. Source: Harding et al. (2010). Reprinted with permission of the author. 
TABLE 1.

Observations of spawning and spawning attempts during the 2010 to 2012 study period, with numbers of female (F) and male (M) individuals, and viability (see text).

\begin{tabular}{lcccc}
\hline \hline \multicolumn{1}{c}{ Date } & Spawn? & $\boldsymbol{n}$ & F/M $(\boldsymbol{n})$ & Viable yes/no (n) \\
\hline July 1, 2010 & Y & 22 & $16 / 6$ & $15 / 1$ \\
August 5, 2010 & No & & & \\
May 3, 2011 & No & & & \\
May 17, 2011 & No & & & \\
May 31, 2011 & No & & & \\
June 7, 2011 & Yes & 18 & $13 / 5$ & $13 / 0$ \\
June 14, 2011 & No & & & \\
June 21, 2011 & Yes & 3 & $1 / 2$ & \\
June 28, 2011 & No & & & \\
July 19, 2011 & No & & & \\
May 16, 2012 & No & & & \\
May 22, 2012 & Yes & 6 & $6 / 0$ & $1 / 0$ \\
May 30, 2012 & Yes & 12 & $10 / 2$ & $10 / 0$ \\
June 6, 2012 & Yes & 37 & $26 / 11$ & $26 / 0$ \\
June 13, 2012 & No & & & \\
July 11, 2012 & Yes & 21 & $12 / 9$ & $11 / 1$ \\
Total & & 119 & $84 / 35$ & $82 / 2$ \\
\hline
\end{tabular}

for each collection was a minimum of 100 oysters (typically 130 150) with shell length (SL) as defined here as the maximum dimension from the hinge to the growing edge, in excess of $30 \mathrm{~mm}$ and including all lengths present in the demographic. The choice of OSH in the immediate vicinity of collection was important in minimizing local impacts of water quality on experimental work described later. Local water quality is influenced by watershed runoff, and the western shore tributaries of the Chesapeake Bay vary markedly in both watershed area and land use within those watersheds.

Oysters were cleaned and maintained overnight at ambient temperature out of water in a damp container. The following morning, approximately 65 oysters, representing the entire size demographic, were transferred to a spawning table flooded with filtered seawater at ambient temperature and subjected to thermal cycling (ambient, $+10^{\circ} \mathrm{C}$, ambient, $+10^{\circ} \mathrm{C}$ at 30 -min intervals) for a maximum of 3 cycles. Between 5 oysters and 10 oysters from those not transferred to the table were shucked and examined for eggs or sperm by smear tests and microscopic examination. Active sperm, when present, were added to the spawning table water at the second thermal cycling if no spawning was observed at the first cycle. If spawning occurred, males were left on the table. Spawning females were removed to individual dishes of filtered seawater to complete the spawning process (approximately $15 \mathrm{~min}$ ). Fecundity was estimated from the mean cell count of triplicate subsamples and the known mixed volume of the dish from which the sample was taken. A subsample of eggs was removed from each spawning female, fertilized using a common mixed pool of sperm, and examined at $24 \mathrm{~h}$ for the presence of D-stage larvae (egg viability as + or -). Nonspawning animals were returned to the river at a site ensuring they would not be resampled in subsequent collections.

\section{Disease Prevalence and Intensity}

All spawning individuals and a subset of nonspawners from each interval were retained and examined subsequently to determine the prevalence and intensity of Haplosporidium nelsoni and Perkinsus marinus as well as any other notable pathological conditions. Transverse sections of oyster tissues including gills, mantle, stomach, intestine, gonad, digestive gland, and associated connective tissues were processed using standard histological methods for microscopic observation of both parasites in 6- $\mu \mathrm{m}$, hematoxylin and eosin-stained paraffin sections. Infections by $H$. nelsoni were rated rare, light, moderate, or heavy in intensity according to Carnegie and Burreson (2011). Infections by $P$. marinus were rated similarly using the following standard: observation of 1-10 cells or small clusters of cells indicated an infection that was rare; 11-40 cells or small clusters, light infection; larger numbers but still primarily within the gut epithelium, moderate infection; and more intense infection spreading into connective tissues and hemal spaces, heavy infection. In 2010 and 2011 samples only, P. marinus was also detected using an adaptation of Ray's fluid thioglycollate assay (RFTM), with infections again characterized as rare through heavy (Audemard et al. 2008).

Additional perspective on oyster disease in Chesapeake Bay was provided by the VIMS Oyster Disease Monitoring Program, which has three components as described in Carnegie and Burreson (2009, 2011): a fall survey of $\sim 30$ oyster reefs in the James, York, Piankatank, Rappahannock, and Great Wicomico rivers and Mobjack Bay; a James River quarterly survey of four reefs in that river; and monthly (May to November) evaluation of spring imports, naive sentinels from the generally disease-free upper Rappahannock River to the disease-intense York River.

\section{Estimation of Spawning Frequency: Degree-day Functions and Condition Index}

Oysters are poikilotherms. Metabolic rates are temperature dependent. Storage metabolism, gametogenesis, vitellogenesis, and spawning proceed in a time-sequenced manner driven by temperature (Gabbott 1975, Mann 1979, Thompson et al. 1996). This temporal sequence for Crassostrea virginica has been described in terms of a predictive degree-day estimator by Price and Maurer (1971) and Mann et al. (1994) as

$$
D^{\prime}=d\left(t-t_{o}\right)
$$

where $d$ is the number of days to attain a ripe state, $t$ is the temperature to which oysters are exposed (ambient field temperatures), and $t_{o}$ is the temperature below which no evidence of gonad development is found.

Price and Maurer (1971) used a value of $12.0^{\circ} \mathrm{C}$ for $t_{o}$ and estimated a value of 450 for $D^{\prime}$ using Delaware Bay Crassostrea virginica. Mann et al. (1994) examined oysters spawning at Horsehead Reef in the James River in 1988. Spawning dates are estimated for June 22, July 27, and August 17, 1988. Using $12.0^{\circ} \mathrm{C}$ for $t_{o}$ and York River, Virginia, water temperatures as surrogates, estimates of $D^{\prime}$ of 420,449 , and 443 , respectively, were generated, with a mean value for $D^{\prime}$ of 434 . Using the previously described records of water temperature for Palace Bar reef, a sequence of projected spawning dates was developed for each of 2010 through 2012.

Spawning activity results in a short-term loss in tissue weight relative to shell weight. The ratio of these values is expressed as a condition index $(\mathrm{CI}=($ Dry meat weight $\times 100) /$ Dry shell weight), per Walne and Mann (1975), Mann (1978), 


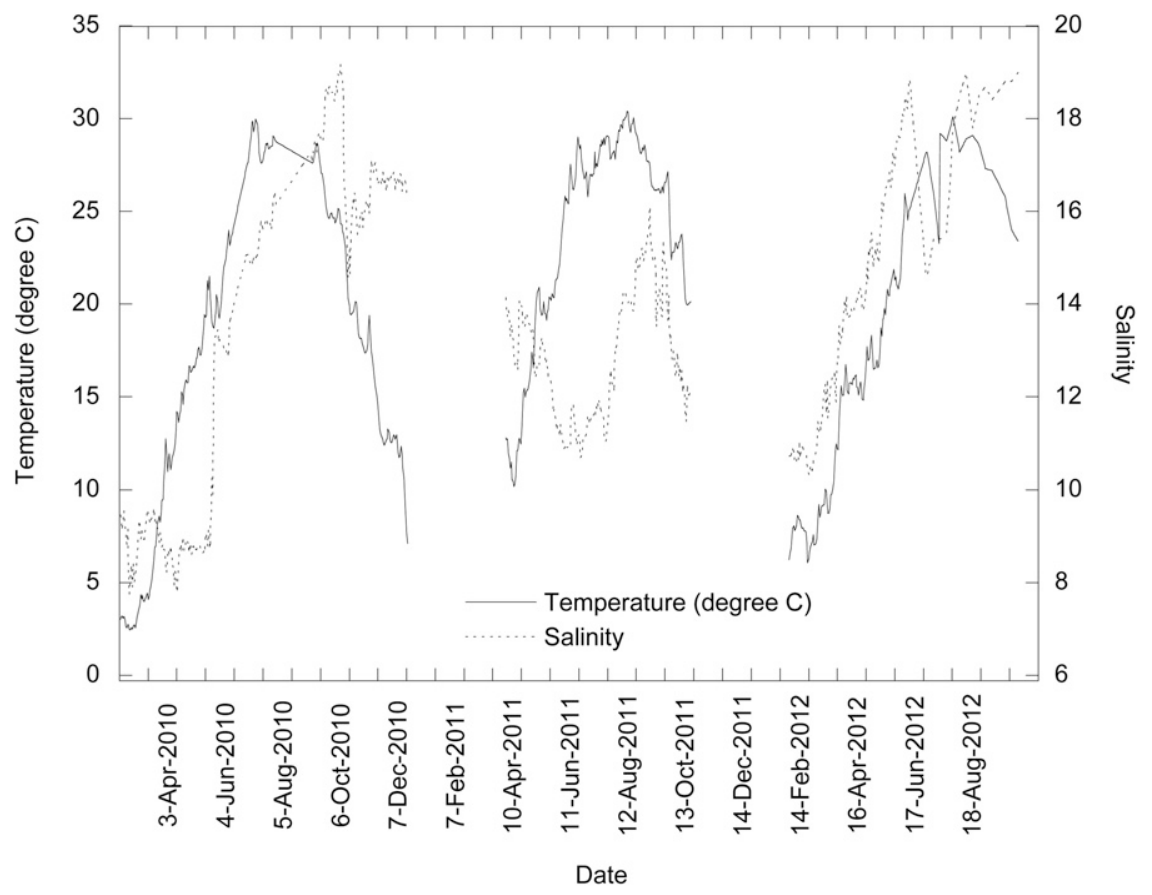

Figure 2. Field temperature and salinity at Palace Bar Reef (labeled PBR in Fig. 1) for period 2010 to 2012.

and Rainer and Mann (1992). In the current study, a separate subsample of 25 individual oysters from the original collection was frozen for subsequent estimation of the CI, and the temporal sequence in the population examined.

\section{RESULTS}

\section{Temperature and Salinity}

In each of the study years, summer temperature reached $30^{\circ} \mathrm{C}$ (Fig. 2). This occurred in July 2010, and in August in both 2011 and 2012. Salinity rose gradually during all 3 y to annual maxima of approximately 18 in September 2010 and July 2012, and 16 in September 2011. These are comparable with longer term values reported in Harding et al. (2010), and annual monitoring reports focused on temporal and spatial recruitment patterns (Southworth \& Mann 2013).

\section{Estimation of Oyster Fecundity and Egg Viability}

Hatchery spawning with viable eggs was observed on 7 dates (July 1, 2010, June 7, 2011, June 21, 2011, May 22, 2012, May 30, 2012, June 6, 2012, July 11, 2012; total $n=119$ oysters, 35 male, 84 female). The number of individuals spawning on each date is given in Table 1. Oysters were opened to examine sex ratio on 4 additional dates $(n=242$ oysters, 82 male, 160 female; Table 2).

The female fraction $(\mathrm{F} / \mathrm{F}+\mathrm{M})$ was consistently more than 0.5 in oysters larger than $60 \mathrm{~mm}$ in SL (estimated age, $\geq 2 \mathrm{y}$ using the quadratic length-age estimator of Harding et al. (2010, Table 11; $n=72$, years 2003 to 2009 where $\mathrm{SL}=a \times$ $(\text { Age })^{2}+b \times($ Age $)+c$, and values of $a, b$, and $c$ are $-2.95,32.66$, and 14.45 , respectively).
Individual fecundity varied between $10^{5}$ eggs and $1.2 \times 10^{8}$ eggs. Fecundity (in years) versus SL (in millimeters) is presented in a series of 3 plates in Figure 3. Figure 3A presents all data by year for all years $(n=84)$. Only modest spawning was observed in $2010(n=16)$ and $2011(n=14)$; thus, Figure 3B presents data for the two major spawning events in 2012 (May 30, 2012, and June 6,2012$)$ only with a fitted allometric curve $(y=0.46 \times$ $\mathrm{SL}^{3.94}, R^{2}=0.37, n=36$ ). Figure $3 \mathrm{C}$ presents data for the same two major events in 2012 when individual values exceed $5 \times 10^{6}$ with the fitted curve $\left(y=2175 \times \mathrm{SL}^{2.19}, R^{2}=0.31, n=26\right)$. The exclusion proceeding from Figure $3 \mathrm{~B}$ to Figure $3 \mathrm{C}$ is based on

TABLE 2.

Sex ratio by size for observed spawning individuals by size (see Table 1) plus additional oysters opened during laboratory procedures (see text).

\begin{tabular}{lcccc}
\hline \hline Size (mm) & Female $(\boldsymbol{n})$ & Male $(\boldsymbol{n})$ & $\begin{array}{c}\text { Fraction } \\
\text { Female }\end{array}$ & $\begin{array}{c}\text { Individuals in each } \\
\text { size range }(\boldsymbol{n})\end{array}$ \\
\hline$<60$ & 2 & 7 & 0.22 & 9 \\
$61-65$ & 6 & 4 & 0.6 & 10 \\
$66-70$ & 12 & 7 & 0.63 & 19 \\
$71-75$ & 17 & 13 & 0.57 & 30 \\
$76-80$ & 30 & 12 & 0.71 & 42 \\
$81-85$ & 25 & 13 & 0.66 & 38 \\
$86-90$ & 22 & 10 & 0.69 & 32 \\
$91-95$ & 16 & 6 & 0.72 & 22 \\
$96-100$ & 18 & 4 & 0.82 & 22 \\
$101-105$ & 7 & 2 & 0.78 & 9 \\
$106-110$ & 1 & 3 & 0.25 & 4 \\
$>111$ & 4 & 1 & 0.8 & 5 \\
Total & 160 & 82 & 0.66 & 242 \\
\hline
\end{tabular}



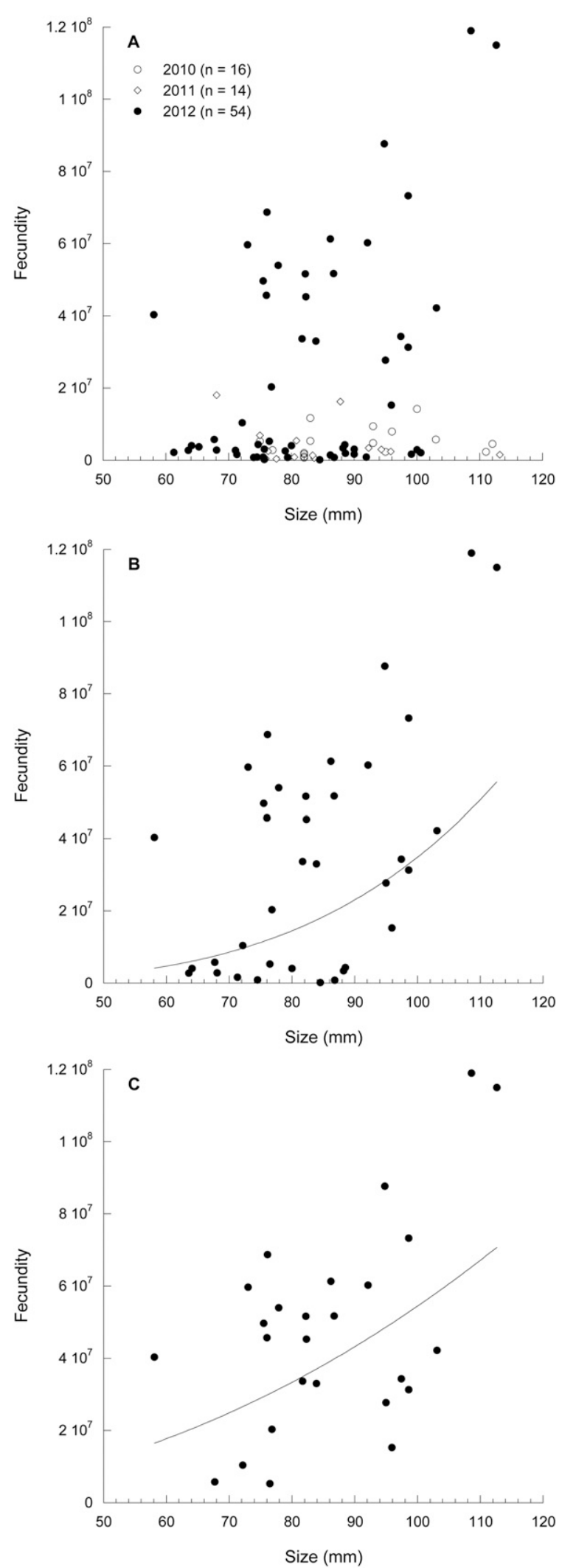

Figure 3. Shell length (SL) versus fecundity (y). (A) All spawning events for the period 2010 to 2012. (B) Spawning events on May 30, 2012, and June 6, $2012(n=36)$. The power fit is $y=0.4626 \times \mathrm{SL}^{3.94} ; R^{2}=0.37$. (C) Spawning events on May 30, 2012, and June 6, 2012, excluding values less than $5 \times 10^{6}(n=26)$. The power fit is $y=2175 \times \mathrm{SL}^{2.19} ; R^{2}=0.31$. the estimate that fecundity less than $5 \times 10^{6}$ represents minimal spawning equivalent to less than $1 \%$ of the remaining values in the plot. Note the changing exponent with exclusion of the low values - from an unreasonable value of 3.94 (unacceptable in that extrapolation to even marginally larger animals results in weight of eggs exceeding total tissue weight) to a value of 2.19 , effectively scaling with the square of length (a tubular analog). This scaling function is similar to that reported for general oyster allometry (Powell et al. in prep.).

\section{Disease Prevalence and Intensity}

Levels of both Haplosporidium nelsoni and Perkinsus marinus were low in Piankatank River samples collected for this study. The infectious $H$. nelsoni was detected at $2.5 \%$ prevalence on the one sampling date in August 2010, and at prevalences ranging from $2.8 \%-13.3 \%$ on 3 of the first 4 sampling dates in 2011 (May 17, May 31, June 7). It was undetected after that and throughout 2012. Without exception, these represented just 1 or (in one case) two observations in a sample, and just a single infection reached light intensity; all others were rare. Therefore, H. nelsoni cannot be viewed as having impacted this study.

Levels of Perkinsus marinus infections were greater, reaching $55.0 \%$ prevalence (as determined histologically) in 2010 when an August sample was collected, the latest in any year of the study; $33.3 \%$ prevalence in 2011 , when samples were collected between May and mid July; and 25.5\% prevalence in 2012, when samples were collected over a similar time frame (Fig. 4A). Weighted prevalences (again determined histologically) were very low in study samples, however, reflecting the absence of serious infections (Fig. 4B). Weighted prevalences in 2011 and 2012 were less than 0.5 , meaning that the average oyster had a rare infection. Just five infections reached moderate intensity during these years. Weighted prevalence was greater (1.09) in the single 2010 sample, collected in August, but this still means the average oyster only had a light infection. Ray's fluid thioglycollate assay-based weighted prevalences for 2010 and 2011 support the histological portrait of $P$. marinus parasitism. An RFTM-based weighted prevalence of 1.75 in the August 2010 sample suggests only a modest level of $P$. marinus-caused Dermo disease. Weighted prevalences ranging from $0.23-0.90$ in 2011 suggest inconsequential parasitism during the time period in which samples were collected.

Data collected for Ginney Point during the fall survey (open diamonds in Figs. 4A, B) for Perkinsus marinus infections reveal far higher prevalences and weighted prevalences in autumn than in spring and summer, an indication that the parasite thrives in the Piankatank River but was simply well below its autumn peak each year during the time periods when study samples were collected.

Given that the overall data for Perkinsus marinus suggest a minimal early season impact, there is little justification for comparing $P$. marinus levels in spawning oysters versus nonspawners. Nonetheless, there were five dates on which two groups of samples, spawners and nonspawners, were analyzed. Prevalence of $P$. marinus was greater in spawning oysters on 3 of the 5 dates, and averaged $14.1 \%$ over all 5 . For the same 5 samples, prevalence of $P$. marinus in nonspawning oysters was $8.1 \%$. 

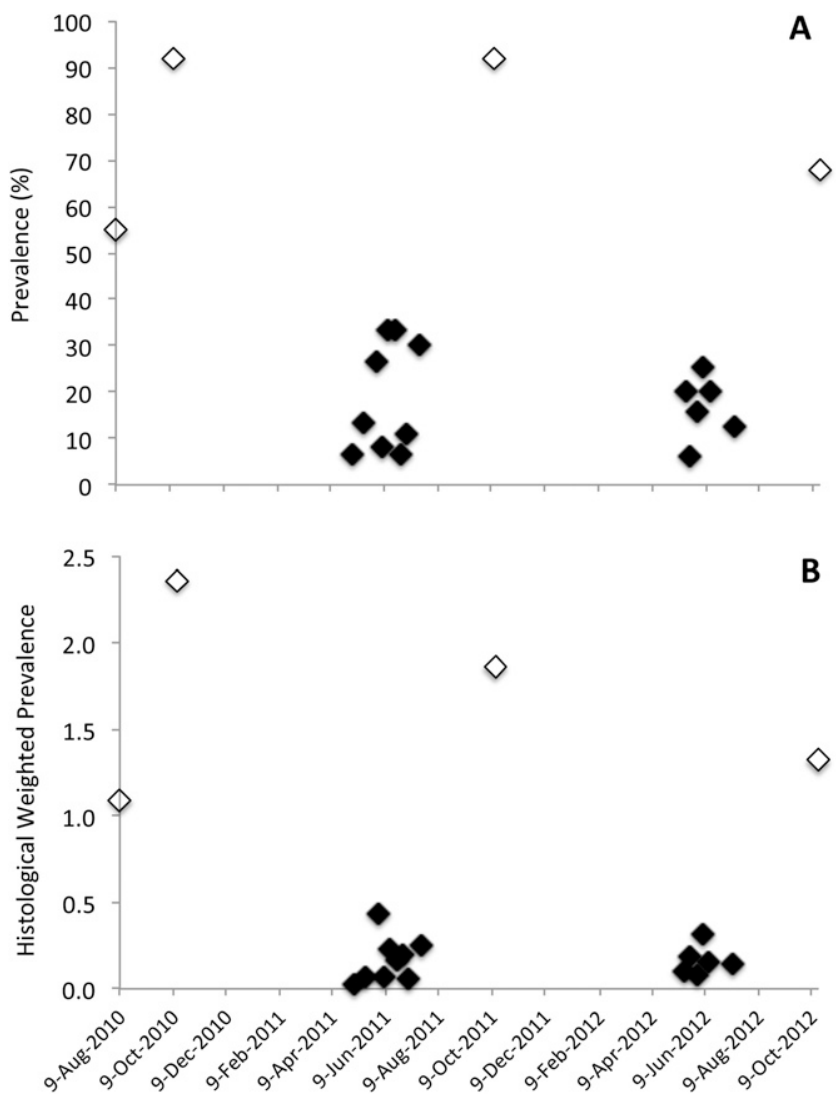

Figure 4. Infection by Perkinsus marinus in Piankatank River oysters as determined histologically. (A) Percentage of prevalence. (B) Weighted prevalence. Filled diamonds represent study samples; open diamonds represent fall survey samples (as discussed in text).

There were insufficient numbers of Perkinsus marinus infections in the 2011 and 2012 samples to permit an analysis of size-specific infection levels. In the August 2010 sample, however, the 40 oysters ranged in size from $63.3-106.8 \mathrm{~mm}$ and displayed a range of infection intensities. The 20 smaller oysters $(63.3-81.7 \mathrm{~mm})$ displayed lower weighted prevalences than the
20 larger oysters $(81.8-106.8 \mathrm{~mm})$ by RFTM (1.50 vs. 2.00$)$ and histology ( 0.95 vs. 1.13), although the frequency of "serious" moderate to heavy infections in the 2 size groups was similar: 0.15 (smaller) versus 0.10 (larger) as judged by RFTM, and 0.25 in each case by histology. Neither size group appeared markedly healthier than the other.

\section{Temporal Spawning Sequence}

Table 3 provides a comparison of observed and estimated, from degree-day data, frequency of spawning. A consistent sequence of up to 5 spawning events is predicted to occur on approximate Julian days 150-156, 170-184, 206-210, 232-237, and 262-267. Concurrence of estimated and observed events in 2010 (spawning 2), 2011(spawnings 1 and 2) and 2012 (spawning 2). Spawning before (2012) or between the predicted dates (2011 and 2012) was also observed, indicating asynchrony in gametogenesis among individuals within the population. Of note is the lack of spawning later in the summer in all years, an observation strengthened by independent observations by commercial hatchery operators.

Histological analyses provided additional perspective on spawning. Most oysters in the sample from early August 2010 were ripe and still releasing at least small numbers of gametes at that stage. In 2011, oysters were in early gametogenic development on May 3, but many were mature and beginning to spawn by May 17, and gradual spawning continued without a dramatic peak and recovery at least through the end of sampling on July 19. In 2012, oysters were generally late in development by May 16, with half or more beginning to spawn by May 22. As in 2011, gradual spawning continued in 2012, at least through the end of sampling in July. Spawning is characterized in oysters as a dramatic release; however, the possibility of an ongoing intermittent low level of "dribble" spawn cannot be entirely discounted. Such behavior would be unrecorded on the spawning table and in Table 1. Histological examination presents evidence of egg evacuation, but the time course of such limited spawning is both difficult to examine in the current design and to quantify for comparison with data described later.

TABLE 3.

A comparison of estimated spawning events during 2010 to 2012 based a cumulative degree day (D') value of 443 (see text).

\begin{tabular}{|c|c|c|c|c|c|c|}
\hline Date & Julian day & Temperature $\left({ }^{\circ} \mathrm{C}\right)$ & Salinity & Degree-day & Estimated spawning & Observed spawning \\
\hline June 4, 2010 & 156 & 24.5 & 14.1 & 440.7 & 1 & \\
\hline July 2, 2010 & 184 & 27.6 & 15.8 & 878.8 & 2 & July 1,2010 \\
\hline July 28, 2010 & 210 & 28.5 & 16.4 & $1,308.6$ & 3 & \\
\hline August 24, 2010 & 237 & 27.7 & 17.2 & $1,741.9$ & 4 & \\
\hline September 24, 2010 & 267 & 25.2 & 19 & $2,169.1$ & 5 & \\
\hline June 3, 2011 & 154 & 26.9 & 11.8 & 446.9 & 1 & June 7, 2011 \\
\hline July 1, 2011 & 182 & 27.4 & 11.7 & 873 & 2 & June 21, 2011 \\
\hline July 27, 2011 & 208 & 29.7 & 13.8 & 1,306 & 3 & \\
\hline August 21, 2011 & 233 & 28.6 & 15.1 & $1,738.4$ & 4 & \\
\hline September 21, 2011 & 264 & 22.8 & 13 & $2,174.4$ & 5 & \\
\hline May 29, 2012 & 150 & 25.5 & 18.4 & 444.7 & 1 & May 22, 2012 \\
\hline June 27, 2012 & 179 & 26.3 & 15.3 & 868.6 & 2 & May 30, 2012 \\
\hline July 24, 2012 & 206 & 28.7 & 18.3 & $1,302.2$ & 3 & June 6, 2012 \\
\hline August 19, 2012 & 232 & 28 & 18.6 & $1,736.6$ & 4 & July 11, 2012 \\
\hline September 18, 2012 & 262 & 24.5 & 18.8 & 2,173 & 5 & \\
\hline
\end{tabular}


Figure 5 illustrates the relationship between SL and dry tissue weight (W; in grams) in all CI samples. The power fit $\left(\mathrm{W}=0.0002 \times \mathrm{SL}^{1.97}, R^{2}=0.31, n=375\right)$ has an exponent value similar to that for the SL versus fecundity relationship in Figure $3 \mathrm{C}$ for fecundity values in excess of $5 \times 10^{6}$; however, there is considerable scatter around the fitted line, indicating variation in dry weight at any chosen value of SL.

Table 4 summarizes temporal changes in the CI of population subsamples throughout the study period. Within each subsample, chosen to represent the size range of individuals examined, the standard deviation of the CI varied between $26 \%$ and $45 \%$ of the mean, indicating large within-sample variation. This is consistent with the data of Figure 5 and Table 3 in indicating asynchrony in the storage-gametogenesis-spawning continuum. Note that even on dates when spawning was observed in hatchery conditions, the majority of the individuals did not spawn; compare the number spawning in Table 3 versus the sample size of 65 submitted to thermal cycling.

\section{DISCUSSION}

There are relatively few published descriptions of the size versus fecundity relationship in field-collected oysters that are not compromised by artifacts that, in turn, lessen the value of such data for field application in developing stock recruit models for natural population management for either restoration or fishery purposes. Hatchery procedures may use excessive thermal stimulation or be based on "stripping" of gametes. Cox and Mann (1992) examined field collections from the James River, Virginia, but complicated interpretation of fecundity values by freezing and subsequently thawing specimens, resulting in probable egg destruction and/or incomplete recovery. Thompson et al. (1996) developed a size versus fecundity estimator based on a subset of the data from Cox and Mann (1992). The exponent of this descriptive fit $\left(y=39.07 x^{2.36}\right)$, where $y$ is fecundity and $x$ is dry tissue weight, is incompatible with even modest extrapolation given that it is much greater than 1.0, and therefore of questionable general value. Choi et al.

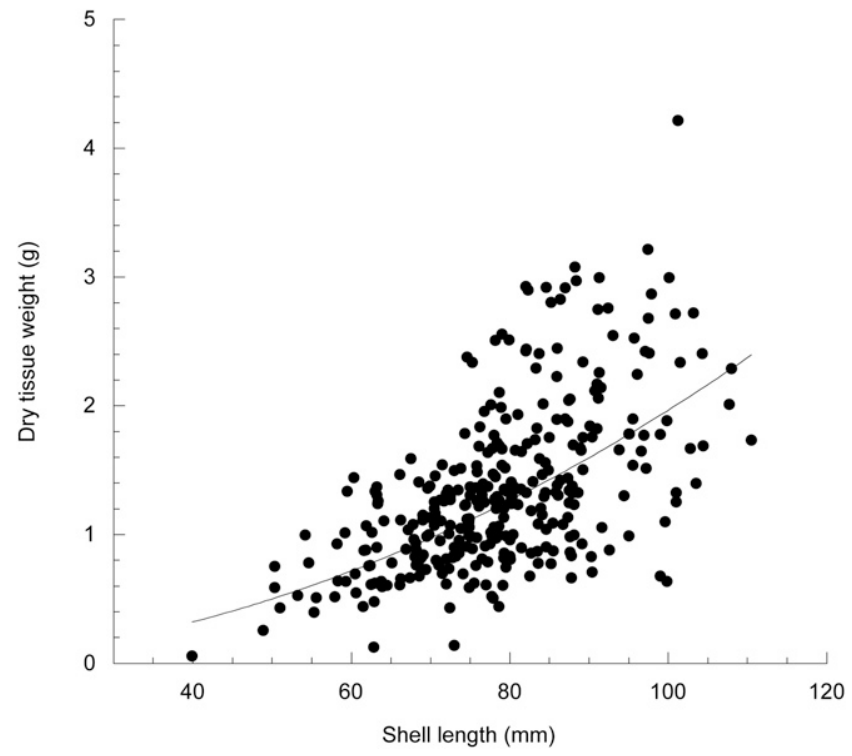

Figure 5. Shell length (SL) versus dry tissue weight (W). The power fit is $\mathrm{W}=0.002 \times \mathrm{SL}^{1.97} ; R^{2}=0.31(n=375)$.
(1993) used an immunoassay, enzyme-linked immunosorbent assay, procedure approach to egg protein to estimate fecundity on oysters collected from West Bay, Texas, and report an almost linear relationship between body weight and egg number in ripe oysters $\left(y=19.86 x^{1.17}\right)$. Galtsoff $(1930)$ provided fecundity values based on eggs released by a limited number of large oysters; length and fecundity (single spawning release) values are $92 \mathrm{~mm}, 94 \mathrm{~mm}, 112 \mathrm{~mm}$, and $133 \mathrm{~mm}$ and 30.3 million, 114.8 million, 15.0 million, and 70.3 million, respectively. When these lengths are examined in the context of the fitted line in Figure 3C, the estimated fecundity values are 45.5 million, 47.7 million, 70.1 million, and 102 million, respectively. When corrected for length of the individual oyster, values reported by Galtsoff (1930) are comparable with those in the current study.

Galtsoff (1930) summarizes reports for Crassostrea virginica (then Ostrea virginica) fecundity to that date thus: Brooks (1880) with an "average-size oyster" of more than 9 million eggs, and an "unusually large" oyster producing 60 million eggs in 1 summer. Nelson (1921) indicated that a large oyster "if fat the preceding spring, undoubtedly would mature from 50 million to 60 million eggs in a season. (p. 8)" Again, these values are in a comparable range with the current study. Studies of Crassostrea gigas by Galtsoff (1930) also reported 11.4-55.8 million eggs released per spawning, but these did not provide accompanying length data.

Significantly, the observed egg production occurred against a backdrop of still intense parasitic disease pressure in the Chesapeake Bay region. Although Haplosporidium nelsoni impacts wane (Carnegie \& Burreson 2011), peak annual Perkinsus marinus levels remain greater than those that preceded the intensification of Dermo disease during the 1980s (Andrews 1984, Burreson \& Andrews 1988). Although autumn abundance (i.e., weighted prevalence) of $P$. marinus in the Piankatank River was typically high, impacts on gametogenesis and spawning were minimal. Our results are thus supportive of early findings by Kennedy et al. (1995), who found that, although serious $P$. marinus infections can impact oyster reproduction significantly, autumn $P$. marinus levels are not predictive of reproductive success in the subsequent year; and by Dittman et al. (2001), who found that $P$. marinus impacts on reproduction are most profound when imposed during gametogenesis, rather than on mature individuals about to spawn. In particular, during the impressive spawn of 2012, the oysters were not affected seriously by $P$. marinus infections of several months earlier, from which they had recovered, or by infections emerging early enough to affect gametogenesis, which probably were present but at a low frequency below the level of detection in our sampling. It is noteworthy that the studies by Kennedy et al. (1995) and Dittman et al. (2001) were conducted more than 20 years ago, in 1990 and 1991. The lack of interference in oyster reproduction by P. marinus two decades later may reflect developing resistance or tolerance to infection, neither concept of which is well defined with respect to this host-parasite system. It must be viewed as 1 possible key to the resilience of this key estuarine species.

What are the implications of the current findings for management and future stability of the oyster populations in the Piankatank River? To address this question we assembled size-specific oyster density estimates from each reef identified in Figure 1 from as yet unpublished fall 2012 stock assessment surveys (Methods in Mann et al. (2009b), and Harding et al. (2010) and Southworth et al. (2010)). The data were then 
TABLE 4.

Temporal sequence of condition index of population subsamples $(n=25$ per sample) for the study period.

\begin{tabular}{|c|c|c|c|c|c|c|c|}
\hline Date & Length (mm) & SD & $\begin{array}{l}\text { Dry meat } \\
\text { weight (g) }\end{array}$ & SD & Condition index & SD & Spawn? \\
\hline June 8, 2010 & 77.4 & 11.66 & 1.59 & 0.73 & 2.55 & 0.75 & No \\
\hline July 1, 2010 & 82.3 & 8.64 & 1.36 & 0.54 & 1.73 & 0.57 & Yes \\
\hline August 9, 2010 & 79.9 & 12.70 & 0.87 & 0.54 & 1.20 & 0.50 & No \\
\hline May 3, 2011 & 83.8 & 13.35 & 1.12 & 0.49 & 1.38 & 0.43 & No \\
\hline May 17, 2011 & 79.4 & 13.35 & 1.34 & 0.56 & 1.89 & 0.47 & No \\
\hline May 31, 2011 & 75.0 & 10.05 & 1.13 & 0.43 & 2.09 & 0.93 & No \\
\hline June 7, 2011 & 80.6 & 11.39 & 1.32 & 0.51 & 1.86 & 0.49 & Yes \\
\hline June 14, 2011 & 82.0 & 9.70 & 1.27 & 0.59 & 1.72 & 0.51 & No \\
\hline June 21, 2011 & 83.8 & 13.35 & 1.12 & 0.49 & 1.38 & 0.43 & Yes \\
\hline May 16, 2012 & 76.0 & 6.83 & 1.51 & 0.33 & 3.03 & 1.05 & No \\
\hline May 22, 2012 & 72.1 & 13.20 & 1.65 & 0.86 & 3.82 & 1.22 & Yes \\
\hline May 30, 2012 & 76.0 & 6.83 & 1.51 & 0.33 & 3.03 & 1.05 & Yes \\
\hline June 6, 2012 & 74.6 & 13.63 & 1.60 & 0.82 & 3.03 & 0.81 & Yes \\
\hline June 13, 2012 & 79.6 & 10.54 & 1.58 & 0.79 & 2.79 & 0.99 & No \\
\hline July 11, 2012 & 81.4 & 10.72 & 1.18 & 0.43 & 1.74 & 0.44 & Yes \\
\hline
\end{tabular}

Data presented as mean \pm SD for length, dry meat weight, and condition index (Weight $\times 100 / S$ ), where $S$ is the dry shell weight (in grams).

aggregated for the entire river system to examine contribution to the total egg production by size class within the population. A summary is provided in Table 5. Age classes were segregated from length demographics using the length-at-age relationship from Harding et al. (2010), with ages corresponding to a "birth date" of July 1. All young of the year were excluded, thus ages are described as $1.3 \mathrm{y}, 2.3 \mathrm{y}, 3.3 \mathrm{y}, 4.3 \mathrm{y}$, and $5.3 \mathrm{y}$ or more. The sex ratio (percentage female) of the age classes was based on Harding et al. (2013), noting the transition from male to female with increasing age. For the 2012 assessment, the 2-y age class represents $50 \%$ of the total oysters by number and $32.7 \%$ of the egg production (2010 was a year of exceptional recruitment whereas 2011 was a poor recruitment year). In contrast, the 3-y age class represents $28 \%$ of the total by number but $45.3 \%$ of the total egg production. The population is severely age truncated, with age classes 3 y and older representing $5.8 \%$ of the total by number but contributing $19.5 \%$ of the egg production. The disproportionate value of the age $3 \mathrm{y}$ and older classes in egg production is noted: $34 \%$ of the total by number but contributing $64.8 \%$ of the egg production.

Of concern in the current study is the consistent lack of spawning in the latter portion of the summer period, an observation also related by the hatchery operators at $\mathrm{OSH}$, where the study was conducted, and the lack of observed recruitment to shell strings in annual recruitment surveys (Southworth et al. 2011, Southworth \& Mann 2012, Southworth \& Mann 2013). The reason for this temporal truncation (compare observations with projected number of spawnings in Table 3 and historical records of oyster spawning dates, as summarized in Haven and Fritz (1985), Austin et al. (1996), and Thompson et al. (1996)) is not known. The incidence and intensity of harmful algal blooms (HAB) in the Virginia estuaries in mid-tolate summer has been notable in recent years (K. Reece, VIMS, pers. comm. 2013) although a comprehensive understanding of both individual $\mathrm{HAB}$ species dynamics and toxicity in these locations remains a subject of investigation rather than a wellestablished body of knowledge. Potentially detrimental HAB impacts on Crassostrea virginica gametogenesis and spawning have not been evaluated, but if they exist it is reasonable to assume these impacts would be focused on late-season reproductive activities. A second possibility is that earlier reproduction is an adaptive response to intensified Perkinsus marinus parasitism. As noted earlier, serious $P$. marinus infections can be disruptive to oyster gametogenesis (Dittman et al. 2001). These infections are most widespread later in the oyster's reproductive season, from August to October, during the parasite's seasonal

TABLE 5.

Mean oyster density and egg production, corrected for sex ratio by age class from the 2012 fall survey (see text).

\begin{tabular}{lcccccc}
\hline \hline & \multicolumn{5}{c}{ Age class (y) } \\
\cline { 2 - 6 } & $\mathbf{1 . 3}$ & $\mathbf{2 . 3}$ & $\mathbf{3 . 3}$ & $\mathbf{4 . 3}$ & $>\mathbf{5 . 3}$ & All \\
\hline Size class (Lmax) & 40 & 65 & 85 & 95 & $>95$ & 0.8 \\
Average density & 6.2 & 19.4 & 10.8 & 1.5 & 38.7 \\
Total oysters $(n)$ & $6.20 \mathrm{E}+06$ & $1.93 \mathrm{E}+07$ & $1.08 \mathrm{E}+07$ & $1.45 \mathrm{E}+06$ & $7.61 \mathrm{E}+05$ & $3.85 \mathrm{E}+07$ \\
Percentage & 16.1 & 50.2 & 28.0 & 3.8 & 100.0 & 4.0 \\
Sex ratio (\% female) & 36.0 & 60.0 & 75.4 & 83.6 & $4.3 \mathrm{E}+13$ & $4.85 \mathrm{E}+14$ \\
Egg production & $1.18 \mathrm{E}+13$ & $1.58 \mathrm{E}+14$ & $2.20 \mathrm{E}+14$ & 10.6 & 8.9 \\
Egg production (\%) & 2.4 & 32.7 & 45.3 & & \\
\hline
\end{tabular}


epizootic peak (Burreson \& Ragone Calvo 1996). The proportion of the Chesapeake Bay oyster population impacted by such infections expanded dramatically during the 1980s (Burreson \& Andrews 1988), which hypothetically may have selected against a late-spawning segment of the oyster population. Both HAB impacts and oyster diseases, among other possible factors, should receive further attention as potential causes of the temporal truncation in oyster spawning.

Long-term studies of egg-to-recruit relationships are rare in the molluscan literature, but the availability of a 15-y data set for the Piankatank River, and 15-20-y data sets for parts of the James and Great Wicomico rivers in the Virginia Chesapeake Bay offer the option to explore these relationships, given that the current study suggests a strong relationship between dry tissue weight and fecundity (compare the exponents as described earlier), suggesting the former can be used as a proxy for the latter in long-term studies. The Piankatank is generally considered a trap-type estuary with only modest tidal exchange (Andrews 1979), although some recruitment in the river may originate in the Lower Rappahannock, where populations have recovered in recent years with rotational harvest management. The rotational harvest proffered by Harding et al. (2010) addresses a dual reference point approach for sustaining both live oyster populations and shell substrate. The latter is sensitive to harvest of larger oysters, given their individual disproportionate contribution to the shell base. The current data will allow exploration to a refined approach incorporating both maximal shell retention in the system and maintenance of spawning stocks.

\section{ACKNOWLEDGMENTS}

This study was supported by NOAA-NCBO award NA11NMF4570226. We thank Vernon Rowe (VMRC), Adam Crockett (VMRC), Kyle Jones (VMRC), Patricia McGrath (VIMS), Todd Nelson (VIMS), and Michael Congrove (OSH) for their assistance in various aspects of the project. This is VIMS contribution number 3360.

\section{LITERATURE CITED}

Andrews, J. D. 1979. Pelecypoda: Ostreidae. In: A. C. Giese \& J. S. Pearse, editors. Reproduction of marine invertebrates. New York: Academic Press. pp. 293-341.

Andrews, J. D. 1984. Epizootiology of diseases of oysters (Crassostrea virginica), and parasites of associated organisms in eastern North America. Helgol. Meersunters. 37:149-166.

Andrews, J. D. \& J. L. Wood. 1967. Oyster mortality studies in Virginia: VI. History and distribution of Minchinia nelsoni (MSX), a pathogen of oysters in Virginia. Chesap. Sci. 8:1-13.

Audemard, C., R. B. Carnegie \& E. M. Burreson. 2008. Shellfish tissue evaluated for Perkinsus spp. using the Ray's fluid thioglycollate medium culture assay can be used for downstream molecular assays. Dis. Aquat. Organ. 80:235-239.

Austin, H. M., D. A. Evans \& D. S. Haven. 1996. A retrospective time series analysis of oyster, Crassostrea virginica, recruitment (19461993). J. Shellfish Res. 15:565-582.

Barber, B. J., S. E. Ford \& H. H. Haskin. 1988. Effects of the parasite MSX (Haplosporidium nelsoni) on oyster (Crassostrea virginica) energy metabolism: I. Condition index and relative fecundity. J. Shellfish Res. 7:25-31.

Brooks, W. K. 1880. Development of the American oyster. Johns Hopkins University. Studies from the Biological Laboratory, no IV. Baltimore: Johns Hopkins University. 81 pp.

Burreson, E. M. \& J. D. Andrews. 1988. Unusual intensification of Chesapeake Bay oyster diseases during recent drought conditions. OCEANS '88. A Partnership of Marine Interests Proceedings. pp. 799, 802. doi: 10.1109/OCEANS.1988.794899.

Burreson, E. M. \& L. M. Ragone Calvo. 1996. Epizootiology of Perkinsus marinus disease of oyster in the Chesapeake Bay with emphasis on data since 1985. J. Shellfish Res. 7:19-23.

Carnegie, R. B. \& E. M. Burreson. 2009. Status of the major oyster diseases in Virginia, 2006-2008: a summary of the annual oyster disease monitoring program. Gloucester Point, VA: Virginia Institute of Marine Science. 20 pp.

Carnegie, R. B. \& E. M. Burreson. 2011. Declining impact of an introduced pathogen: Haplosporidium nelsoni in the oyster Crassostrea virginica in Chesapeake Bay. Mar. Ecol. Prog. Ser. 432:1-15.

Chen, H. S., P. V. Hyer, A. Y. Kuo \& C. S. Fang. 1977. Hydrography and hydrodynamics of Virginia estuaries: XI. Mathematical model studies of water quality of the Piankatank estuary. Special report no. 124 in Applied Marine Science and Ocean Engineering. Gloucester Point, VA: Virginia Institute of Marine Science. $80 \mathrm{pp}$.

Choi, K.- S., D. H. Lewis, E. N. Powell \& S. M. Ray. 1993. Quantitative measurements of reproductive condition in the American oyster Crassostrea virginica (Gmelin) using an enzyme-linked immunosorbent assay (ELISA). Aquacult. Fish. Manage. 24:299-322.

Cox, C. \& R. Mann. 1992. Temporal and spatial changes in fecundity of oysters, Crassostrea virginica (Gmelin) in the James River, Virginia, U.S.A. J. Shellfish Res. 11:47-52.

Dittman, D. E., S. E. Ford \& D. K. Padilla. 2001. Effects of Perkinsus marinus on reproduction and condition of the eastern oyster, Crassostrea virginica, depend on timing. J. Shellfish Res. 20:10251034.

Engle, J. B. 1950. The condition of oysters as measured by the carbohydrate cycle, the condition factor and the percent dry weight. National Shellfisheries Association convention papers. Washington, D.C.: U.S. Fish and Wildlife Service.

Ford, S. E. \& A. J. Figueras. 1988. Effects of sublethal infection by the parasite Haplosporidium nelsoni (MSX) on gametogenesis, spawning, and sex ratios of oysters in Delaware Bay, USA. Dis. Aquat. Organ. 4:121-133.

Gabbott, P. 1975. Storage cycles in marine bivalve molluscs: a hypothesis concerning the relationship between glycogen metabolism and gametogenesis. In: H. Barnes, editor. Proceedings of the Ninth European Marine Biological Symposium. Aberdeen, Scotland: Aberdeen Press. pp. 191-211.

Galtsoff, P. S. 1930. The fecundity of the oyster. Science 25:97-98.

Gunter, G. 1942. Seasonal condition of Texas oysters. Proc. Trans. Tex. Acad. Sci. 25:89-93.

Harding, J. M., R. Mann, M. Southworth \& J. A. Wesson. 2010. Management of the Piankatank River, Virginia, in support of oyster (Crassostrea virginica, Gmelin 1791) fishery repletion. J. Shellfish Res. 29:867-888.

Harding, J. M., E. N. Powell, R. Mann \& M. Southworth. 2013. Variations in eastern oyster (Crassostrea virginica) sex ratios from three Virginia estuaries related to growth and mortality. J. Mar. Biol. Assoc U K 93:519-531.

Haven, D. S. \& L. W. Fritz. 1985. Setting of the American oyster Crassostrea virginica in the James River, Virginia, USA: temporal and spatial distribution. Mar. Biol. 86:271-282. 
Kennedy, V. S., R. I. E. Newell, G. E. Krantz \& S. Otto. 1995. Reproductive capacity of the eastern oyster Crassostrea virginica infected with the parasite Perkinsus marinus. Dis. Aquat. Organ. 23:135-144.

Mann, R. 1978. A comparison of morphometric, biochemical and physiological indexes of condition in marine bivalve molluscs. In: J. H. Thorp \& J. W. Gibbons, editors. Energy and environmental stress in aquatic systems. D. O. E. Symposium series. Springfield, VA: Nat. Tech. Inofrmation Service. pp. 484-497.

Mann, R. 1979. Some biochemical and physiological aspects of growth and gametogenesis in Crassostrea gigas (Thunberg) and Ostrea edulis L. grown at sustained elevated temperatures. J. Mar. Biol. Assoc. U K 59:95-110.

Mann, R., J. M. Harding \& M. Southworth. 2009a. Reconstructing preColonial oyster demographics in the Chesapeake Bay, USA. Estuar. Coast. Shelf Sci. 85:217-222.

Mann, R., R. Morales-Alamo \& J. S. Rainer. 1994. Reproductive activity of oysters, Crassostrea virginica Gmelin, in the James River, Virginia, during 1987-1988. J. Shellfish Res. 13:157-164.

Mann, R. \& E. N. Powell. 2007. Why oyster restoration goals in the Chesapeake Bay are not and probably cannot be achieved J. Shellfish Res. 26:905-917.

Mann, R., M. Southworth, J. M. Harding \& J. A. Wesson. 2009b. Population studies of the native oyster Crassostrea virginica (Gmelin) in the James River, Virginia, USA. J. Shellfish Res. 28:193-220.

Nelson, T. C. 1921. Aids to successful oyster culture. New Jersey Agricultural Experiment Station, 1921, bulletin 351. New Brunswick, NJ: New Jersey Agricultural Experiment Stations. 59 pp.

Newell, R. I. E. 1988. Ecological changes in Chesapeake Bay: are they the result of overharvesting the American oyster (Crassostrea virginica)? In: M. Lynch, editor. Understanding the estuary: advances in Chesapeake Bay research. Chesapeake Research Consortium publication 129. Gloucester Point, VA: Chesapeake Research Consortium. pp. 536-546.

Powell, E. N. \& H. Cummins. 1985. Are molluscan maximum life spans determined by long-term cycles in benthic communities? Oecologia 67:177-182.

Powell, E. N. \& J. M. Klinck. 2007. Is oyster shell a sustainable estuarine resource? J. Shellfish Res. 26:181-194.
Powell, E. N., J. N. Kraeuter \& K. A. Ashton-Alcox. 2006. How long does oyster shell last on an oyster reef? Estuar. Coast. Shelf Sci. 69:531-542.

Powell, E. N., J. Morson, K. A. Ashton-Alcox \& Y. Kim. 2013. Accommodation of the sex ratio in eastern oysters Crassostrea virginica to variation in growth and mortality across the estuarine salinity gradient in Delaware Bay. J. Mar. Biol. Assoc. U K 93:533-555.

Price, K. S. \& D. Maurer. 1971. Holding and spawning Delaware Bay oysters (Crassostrea virginica) out of season: II. Temperature requirements for maturation of gonads. Proc. Natl. Shellfish. Assoc. 61:29-34.

Rainer, J. S. \& R. Mann. 1992. A comparison of methods for calculating condition index in oysters (Crassostrea virginica, Gmelin). J. Shellfish Res. 11:53-56.

Southworth, M., J. M. Harding \& R. Mann. 2011. The status of Virginia's public oyster resource 2010. Molluscan Ecology Program. Gloucester Point, VA: Virginia Institute of Marine Science. 50 pp.

Southworth, M., J. M. Harding, R. Mann \& J. A. Wesson. 2010. Oyster (Crassostrea virginica Gmelin 1791) population dynamics on public reefs in the Great Wicomico River, Virginia, USA. J. Shellfish Res. 29:271-290.

Southworth, M. \& R. Mann. 2004. Decadal scale changes in seasonal patterns of oyster recruitment in the Virginia sub estuaries of the Chesapeake Bay. J. Shellfish Res. 23:391-402.

Southworth, M. \& R. Mann. 2012. The status of Virginia's public oyster resource 2011. Molluscan Ecology Program. Gloucester Point, VA: Virginia Institute of Marine Science. $51 \mathrm{pp}$.

Southworth, M. \& R. Mann. 2013. The status of Virginia's public oyster resource, 2012. Molluscan Ecology Program. Gloucester Point, VA: Virginia Institute of Marine Science. $50 \mathrm{pp}$.

Thompson, R. J., R. I. E. Newell, V. S. Kennedy \& R. Mann. 1996. Reproductive processes and early development. In: V. S. Kennedy, R. I. E. Newell \& A. F. Eble, editors. The eastern oyster, Crassostrea virginica. College Park, MD: University of Maryland Sea Grant Press. pp. $335-370$.

Walne, P. R., R. Mann \& H. Barnes. 1975. Growth and biochemical composition in Ostrea edulis and Crassostrea gigas. In: H. Barnes, editor. Proceedings of the Ninth European Marine Biological Symposium. Aberdeen: Aberdeen University Press. pp. 587-607. 